\title{
IMPLEMENTASI TEORI BELAJAR BEHAVIORISTIK DALAM
} PEMBELAJARAN

\author{
Elvia Baby Shahbana ${ }^{1}$, Fiqh kautsar farizqi ${ }^{2}$, Rachmat Satria $^{3}$ \\ Program Studi Manajemen Pendidikan \\ Universitas Negeri Malang \\ Jl. Semarang No. 5, Malang, Indonesia
}

\begin{abstract}
ABSTRAK
Penulisan artikel ini bertujuan untuk mengetahui teori belajar Behavioristik dalam pembelajaran, Teori belajar behaviorisme berorientasi pada "hasil yang dapat diukur, diamati, dianalisis, dan diuji secara obyektif". Pengulangan dan pelatihan digunakan supaya perilaku yang diinginkan dapat menjadi kebiasaan. Hasil yang diharapkan dari penerapan teori behaviorisme adalah terbentuknya suatu perilaku yang diinginkan. Perilaku yang diinginkan mendapat penguatan positif dan perilaku yang kurang sesuai mendapat penghargaan negatif. Evaluasi atau penilaian didasarkan pada perilaku yang tampak dalam pembelajaran peserta didik.
\end{abstract}

Kata Kunci : Teori Belajar, Behavioristik, Pembelajaran

\section{PENDAHULUAN}

Secara sederhana, teori belajar adalah suatu prinsip umum atau kumpulan prinsip yang saling berhubungan dan merupakan penjelasan atas sejumlah fakta dan penemuan yang berkaitan dengan peristiwa belajar. Teori belajar adalah suatu tesis-tesis yang mendeskripsikan beragam aspek pada hakikat belajar. Para pemikir dan pakar yang punya keahlian di berbagai bidang keilmuan punya sumbangsih yang penting dalam merumuskan teori-teori belajar. Atau setidaknya, pemikiran-pemikiran mereka tentang manusia dan kehidupan telah digunakan oleh para praktisi pendidikan dan pembelajaran untuk merumuskan teori-teori belajar dan mempraktikkannya dalam kenyataan. Teori-teori belajar telah banyak muncul dalam sejarah peradaban, dimulai dari yang paling awal yakni teori behaviorisme hingga teori belajar humanisme. Seiring dengan berjalannya waktu mengikuti hukum dinamisme kehidupan, teori-teori belajar tampaknya akan terus bermunculan dan bertambah. Biasanya yang hadir kemudian atau belakangan akan mengkritik dan menyempurnakan teori-teori yang sudah ada atau sebelumnya. Dengan adanya teori-teori yang muncul lebih dulu, maka para pemikir, praktisi pendidikan, dan praktisi pembelajaran tertantang untuk mengapresiasi, mempraktikkan, dan menyempurnakannya. Teori yang telah ada lalu diapresiasi, dipraktikkan, dikritik, dan disempurnakan. Kemudian muncullah teori baru yang dipandang lebih baik, lebih sesuai, dan lebih sempurna. Teori baru ini kemudian juga diapresiasi, dikritik, dan disempurnakan sebagaimana teori-teori yang telah berkembang sebelumnya. 
Teori belajar behaviorisme berorientasi pada hasil yang dapat diukur, diamati, dianalisis, dan diuji secara obyektif. Pendekatan ini memiliki kontribusi dalam mencapai perubahan pemikiean, perasaan dan pola perilaku bagi individu (Sanyata, 2012). Pengulangan dan pelatihan digunakan supaya perilaku yang diinginkan dapat menjadi kebiasaan. Hasil yang diharapkan dari penerapan teori behaviorisme adalah terbentuknya suatu perilaku yang diinginkan. Perilaku yang diinginkan mendapat penguatan positif dan perilaku yang kurang sesuai mendapat penghargaan negative. Evaluasi atau penilaian didasarkan pada perilaku yang tampak.

\section{METODE PENELITIAN}

Penulisan artikel ini menggunakan metode kajian literatur, yang bertujuan untuk mencari teori-teori yang di gunakan sebagai sumber rujukan dan di gunakan sebagai referensi. Menurut Sugiono (2005) studi literatur merupakan catatan peristiwa-peristiwa pada masa lalu yang berupa gambar, tulisan, atau pun karya monumental seseorang. Sedangkan menurut Bungin (2008) metode literatur merupakan metode pengumpulan data yang di gunakan pada metodologi penelitian sosial untuk menelusuri data-data yang sudah ada. Langkah-langkah yang dilakukan oleh penulis yang pertama adalah mencari referensi dengan menggunakan keyword dari judul artikel, setelah menemukan referensi yang sesuai penulis menelaah teori kemudian menjambarkan dengan kalimat sendiri.

\section{PEMBAHASAN}

Temuan yang didapatkan dalam penelitian ini adalah menggambarkan teori belajar Behavioristik dalam pembelajaran. Teori belajar Behavioristik merupakan salah satu aliran psikologi yang memandang bahwasannya perilaku belajar seseorang atau individu hanya pada kejadian atau fenomena yang tampak secara kasat mata atau jasmaniah dan mengabaikan aspek-aspek mental hal ini di kemukakan oleh (Soesilo, 2015). Aliran psikologi atau teori belajar behavioristik tidak melibatkan minat, emosi, dan perasaan individu dalam proses belajar. Peristiwa dalam pelaksanaan pembelajaran hanya semata-mata karena stimulus dan respon yang diberikan kemudian hal tersebut menjadi sebuah kebiasaan yang di kuasi oleh individu. Belajar apabila ditinjau dari pandangan behavioristik bisa disederhanakan lagi merupakan suatu bentuk perubahan yang dialami individu berupa kemampuan dalam bentuk perubahan tingkah laku dengan cara yang baru sebagai hasil dari adanya stimulus dan respon. Menurut Sugiyono \& Hariyanto dalam (Irham \& Wiyani, 2015) pokok perhatian dari teori belajar behavioristik adalah belajar akan terjadinya akibat dari adanya interaksi antara stimulus dan respon atau output yang dapat diamati dan dapat diukur. Selain itu juga, menurut teori belajar behaviosritik, meskipun terjadi suatu perubahan mental pada individu setelah melakukan belajar, faktor-faktor tersebut tidak diperhatikan dan tidak dianggap sebagai hasil belajar karena dianggap hal tersebut tidak dapat diamati dan tidak dapat diukur. Maka dari itu, pengukuran menjadi hal yang sangat penting untuk melihat bentuk-bentuk perubahan yang terjadi atau tidak adanya perubahan tingkah laku, dan dalam pelaksanaan pembelajaran teori behavioritik lebih menekankan pada aspek pengguatan (reinforcement). Menurut Rusuli dalam dalam (Husamah dkk, 2018) teori belajar behavioristik semuanya itu timbul setelah manusia mengalami kontak dengan alam dan lingkungan sosial budayanya dalam proses pendidikan. Maka individu akan menjadi sosok yang pintar, terampil, dan mempunyai sifat abstrak 
lainnya tergantung pada apakah dan bagaimana cara ia belajar dengan lingkungannya. Teori belajar behavioristik memiliki ciri-ciri spesifik menurut Rusuli dalam (Husamah dkk, 2018), diantaranya adalah: (1) mementingkan faktor lingkungan, (2) perkembangan tingkah laku seseorang itu tergantung pada belajar, (3) menekankan pada faktor bagian (elemen-elemen dan tidak secara keseluruhan), (4) sifatnya mekanis atau mementingkan reaksi kebiasaankebiasaan, (5) mementingkan masa lalu atau bertinjauan historis artinya segala tingkah lakunya terbentuk karena pengalaman dan latihan.

\section{1) Tokoh-tokoh Teori Behavioristik}

Tokoh-tokoh penting yang mengembangkan teori belajar behavioristik, dapat dijelaskan sebagai berikut: (1) Edward Lee Thorndike mengemukakan bahwa belajar merupakan peristiwa terbentuknya asosiasiasosiasi antara peristiwa-peristiwa yang disebut Stimulus $(S)$ dengan Respon $(R)$. Stimulus adalah suatu perubahan dari lingkungan eksternal yang menjadi tanda untuk mengaktifkan organisme untuk beraksi atau berbuat sedangkan respon dari adalah sembarang tingkah laku yang dimunculkan karena adanya perangsang. Dari eksperimen kucing lapar yang dimasukkan dalam sangkar (puzzle box) diketahui bahwa supaya tercapai hubungan antara stimulus dan respons, perlu adanya kemampuan untuk memilih respons yang tepat serta melalui usaha-usaha atau percobaanpercobaan (trials) dan kegagalan-kegagalan (error) terlebih dahulu. Bentuk paling dasar dari belajar adalah "trial and error learning atau selecting and connecting learning" dan berlangsung menurut hukum-hukum tertentu. Oleh karena itu teori belajar yang dikemukakan oleh Thorndike ini sering disebut dengan teori belajar koneksionisme atau teori asosiasi (Rahyubi, 2012).

Percobaan Thorndike yang terkenal dengan binatang coba kucing yang telah dilaparkan dan diletakkan di dalam sangkar yang tertutup dan pintunya dapat dibuka secara otomatis apabila kenop yang terletak di dalam sangkar tersebut tersentuh. Percobaan tersebut menghasilkan teori "trial and error" atau "selecting and conecting", yaitu bahwa belajar itu terjadi dengan cara mencoba-coba dan membuat salah. Percobaan ini menunjukkan bahwa kucing tersebut cenderung untuk meninggalkan perbuatan-perbuatan yang tidak mempunyai hasil. Setiap respons menimbulkan stimulus yang baru, selanjutnya stimulus baru ini akan menimbulkan respons lagi, demikian selanjutnya, sehingga dapat digambarkan sebagai berikut:

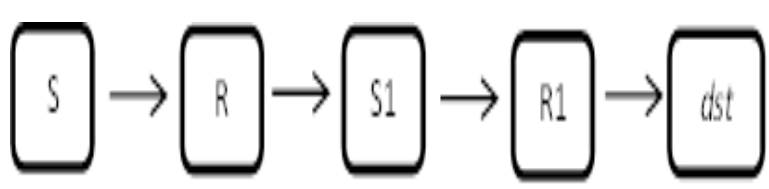

Gambar 1. Rangkaian Teori Balajar

Behaviouristik

Percobaan selanjutnya diletakkan makanan di luar sangkar kucing, maka kucing berusaha untuk mencapainya dengan cara meloncat-loncat kian kemari. Dengan tidak tersengaja kucing telah menyentuh kenop, maka terbukalah pintu sangkar tersebut, dan kucing segera lari ke tempat makan. Percobaan ini diulangi untuk beberapa kali, dan setelah kurang lebih 10 sampai dengan 12 kali, kucing baru dapat dengan sengaja menyentuh kenop tersebut apabila di luar diletakkan makanan.

Menurut Rahyubi (2012) percobaan yang dilakukan Thorndike menemukan hukum-hukum belajar sebagai berikut: (a) Hukum law of readiness (Kesiapan), yaitu semakin siap suatu organisme memperoleh suatu perubahan tingkah laku, maka pelaksanaan tingkah laku tersebut akan menimbulkan kepuasan individu sehingga 
asosiasi cenderung diperkuat. Prinsip pertama teori koneksionisme adalah belajar suatu kegiatan membentuk asosiasi (connection) antara kesan panca indera dengan kecenderungan bertindak. Misalnya, jika anak merasa senang atau tertarik pada kegiatan menggambar, maka ia akan cenderung mengerjakannya. Apabila hal ini dilaksanakan, ia merasa puas dan belajar menggambar akan menghasilkan prestasi yang memuaskan.

Masalah pertama, law of readiness dinyatakan jika kecenderungan bertindak dan orang melakukannya, maka ia akan merasa puas. Akibatnya, ia tak akan melakukan tindakan lain. Masalah kedua, jika ada kecenderungan bertindak, tetapi ia tidak melakukannya, maka timbullah rasa ketidakpuasan. Akibatnya, ia akan melakukan tindakan lain untuk mengurangi atau meniadakan ketidakpuasannya. Masalah ketiga, adalah bila tidak ada kecenderungan bertindak padahal ia melakukannya, maka timbullah ketidakpuasan. Akibatnya, ia akan melakukan tindakan lain untuk mengurangi atau meniadakan ketidakpuasannya. (b) Hukum law of exercise (latihan), yaitu semakin sering tingkah laku diulang/ dilatih (digunakan), maka asosiasi tersebut akan semakin kuat. Prinsip law of exercise adalah koneksi antara kondisi (yang merupakan perangsang) dengan tindakan akan menjadi lebih kuat karena latihanlatihan, tetapi akan melemah bila koneksi antara keduanya tidak dilanjutkan atau dihentikan. Prinsip menunjukkan bahwa prinsip utama dalam belajar adalah ulangan. Makin sering diulangi, materi pelajaran akan semakin dikuasai. (c) Hukum law of effect (akibat), yaitu hubungan stimulus respon cenderung diperkuat bila akibatnya menyenangkan dan cenderung diperlemah jika akibatnya tidak memuaskan. Hukum ini menunjuk pada makin kuat atau makin lemahnya koneksi sebagai hasil perbuatan. Suatu perbuatan yang disertai akibat menyenangkan cenderung dipertahankan dan lain kali akan diulangi. Sebaliknya, suatu perbuatan yang diikuti akibat tidak menyenangkan cenderung dihentikan dan tidak akan diulangi.

Koneksi antara kesan panca indra dengan kecenderungan bertindak dapat menguat atau melemah, tergantung pada "buah" hasil perbuatan yang pernah dilakukan. Thorndike berkeyakinan bahwa prinsip proses belajar binatang pada dasarnya sama dengan yang berlaku pada manusia, walaupun hubungan antara situasi dan perbuatan pada binatang tanpa diperantarai pengartian.

(2) Ivan Petrovich Pavlov, Classic conditioning (pengkondisian atau persyaratan klasik) adalah proses yang ditemukannya melalui percobaannya terhadap anjing, dimana perangsang asli dan netral dipasangkan dengan stimulus bersyarat secara berulang-ulang sehingga memunculkan reaksi yang diinginkan. Eksperimen-eksperimen yang dilakukan Pavlov dan ahli lain tampaknya sangat terpengaruh pandangan behaviorisme, dimana gejala-gejala kejiwaan seseorang dilihat dari perilakunya. Hal ini sesuai dengan pendapat Bakker bahwa yang paling sentral dalam hidup manusia bukan hanya pikiran, peranan maupun bicara, melainkan tingkah lakunya. Pikiran mengenai tugas atau rencana baru akan mendapatkan arti yang benar jika ia berbuat sesuatu (Bakker, 1985). Bertitik tolak dari asumsinya bahwa dengan menggunakan rangsanganrangsangan tertentu, perilaku manusia dapat berubah sesuai dengan apa yang diinginkan. Kemudian Pavlov mengadakan eksperimen dengan menggunakan binatang (anjing) karena ia menganggap binatang memiliki kesamaan dengan manusia. Namun demikian, dengan segala kelebihannya, secara hakiki manusia berbeda dengan binatang. Ia mengadakan percobaan dengan 
cara mengadakan operasi leher pada seekor anjing. Sehingga kelihatan kelenjar air liurnya dari luar. Apabila diperlihatkan sesuatu makanan, maka akan keluarlah air liur anjing tersebut. Sebelum makanan diperlihatkan, maka yang diperlihatkan adalah sinar merah terlebih dahulu, baru makanan. Dengan sendirinya air liurpun akan keluar pula. Apabila perbuatan yang demikian dilakukan berulang-ulang, maka pada suatu ketika dengan hanya memperlihatkan sinar merah saja tanpa makanan maka air liurpun akan keluar pula. Makanan adalah rangsangan wajar, sedang merah adalah rangsangan buatan. Ternyata kalau perbuatan yang demikian dilakukan berulangulang, rangsangan buatan ini akan menimbulkan syarat (kondisi) untuk timbulnya air liur pada anjing tersebut (conditioned respons).

(3) Burrhus Frederic Skinner, Seperti halnya kelompok penganut psikologi modern, Skinner mengadakan pendekatan behavioristik untuk menerangkan tingkah laku dengan pendekatan model instruksi langsung dan meyakini bahwa perilaku dikontrol melalui proses operant conditioning. Di mana seorang dapat mengontrol tingkah laku organisme melalui pemberian reinforcement yang bijaksana dalam lingkungan relatif besar. Dalam beberapa hal, pelaksanaannya jauh lebih fleksibel daripada conditioning klasik. Gaya mengajar guru dilakukan dengan beberapa pengantar dari guru secara searah dan dikontrol guru melalui pengulangan dan latihan. Manajemen Kelas menurut Skinner adalah berupa usaha untuk memodifikasi perilaku antara lain dengan proses penguatan yaitu memberi penghargaan pada perilaku yang diinginkan dan tidak memberi imbalan apapun pada perilaku yanag tidak tepat. Operant Conditioning adalah suatu proses perilaku operant (penguatan positif atau negatif) yang dapat mengakibatkan perilaku tersebut dapat berulang kembali atau menghilang sesuai dengan keinginan.
Skinner membuat eksperimen sebagai berikut: dalam laboratorium Skinner memasukkan tikus yang telah dilaparkan dalam kotak yang disebut "skinner box", yang sudah dilengkapi dengan berbagai peralatan yaitu tombol, alat pemberi makanan, penampung makanan, lampu yang dapat diatur nyalanya, dan lantai yang dapat dialiri listrik. Karena dorongan lapar tikus berusaha keluar untuk mencari makanan. Selama tikus bergerak kesana kemari untuk keluar dari box, tidak sengaja ia menekan tombol, kemudian makanan keluar. Secara terjadwal diberikan makanan secara bertahap sesuai peningkatan perilaku yang ditunjukkan si tikus, proses ini disebut shaping. Berdasarkan berbagai percobaannya pada tikus dan burung merpati Skinner mengatakan bahwa unsur terpenting dalam belajar adalah penguatan. Maksudnya adalah pengetahuan yang terbentuk melalui ikatan stimulus respon akan semakin kuat bila diberi penguatan. Skinner membagi penguatan ini menjadi dua yaitu penguatan positif dan penguatan negatif. Bentuk bentuk penguatan positif berupa hadiah, perilaku, atau penghargaan. Bentuk bentuk penguatan negatif antara lain menunda atau tidak memberi penghargaan, memberikan tugas tambahan atau menunjukkan perilaku tidak senang. Beberapa prinsip Skinner antara lain: (a) hasil belajar harus segera diberitahukan kepada siswa, jika salah dibetulkan, jika benar diberi penguatan; (b) proses belajar harus mengikuti irama dari yang belajar; (c) materi pelajaran, digunakan sistem moduldalam proses pembelajaran, tidak digunakan hukuman. untuk itu lingkungan perlu diubah, untuk menghindari adanya hukuman; (d) dalam proses pembelajaran, lebih dipentingkan aktivitas sendiri; (e) tingkah laku yang diinginkan pendidik, diberi hadiah, dan sebaiknya hadiah 
diberikan dengan menngunakannya jadwal variabel rasio rein forcer; (f) menggunakan pendekatan shaping.

\section{2) Aplikasi Teori Belajar Behavioristik dalam Pembelajaran}

Bentuk pembelajaran behavioristik dapat dilihat dari berbagai hal yang dilakukan selama proses dan pada bentuk pembelajaran. Menurut Irham \& Wiyani (2015) menyebutkan bahwa halhal penting yang merupakan bentuk atau ciri dari proses pembelajaran behavioristik dapat dilihat dari beberapa hal, diantaranya adalah (1) mendudukan siswa sebagai individu yang pasif; (2) memunculkan perilaku-perilaku yang diharapkan menggunakan metode pembiasaanpembiasaan atau drill; (3) memandang pengetahuan merupakan sesuatu yang stagnan dan tidak pernah berubah shingga akan disampikan sama pada setiap tahunnya; (4) memandang mengajar hanya sebagai transfer pengetahuan dan belajar sebagai proses memperoleh pengetahuan; (5) kurikulum dikembangkan secara terstruktur dan pengetahuan sudah ada shingga siswa tinggal mempelajarinya. Sedangkan menurut Sugihartono, dkk (2007) Terdapat beberapa hal yang perlu diperhatikan dalam penerapan teori belajar behavioristik dalam proses pembelajaran sebagai berikut: (1) mementingkan dan memerhatikan pengaruh lingkungan; (2) mengutamakan mekanisme terbentuknya hasil belajar melalui mekanisme stimulus-respon $(S-R)$; mementingkan dan memperhatikan kemampuan yang sudah dimiliki dan terbentuk pada saat-saat sebelumnya; (4) mementingkan pembentukan kebiasaan perilaku melalui latihan dan pengulangan; (5) hasil belajar yang tercapai terwujud dalam bentuk perilaku-perilaku yang diinginkan.

Aliran psikologi belajar yang sangat besar pengaruhnya terhadap arah pengembangan teori dan praktek pendidikan dan pembelajaran hingga kini adalah aliran behavioristik. Aliran ini menekankan pada terbentuknya perilaku yang tampak sebagai hasil belajar. Teori behavioristik dengan model hubungan stimulus responnya, mendudukkan orang yang belajar sebagai individu yang pasif. Respon atau perilaku tertentu dengan menggunakan metode drill atau pembiasaan semata. Munculnya perilaku akan semakin kuat bila diberikan reinforcement dan akan menghilang bila dikenai hukuman. Aplikasi teori behavioristik dalam kegiatan pembelajaran tergantung dari beberapa hal seperti: tujuan pembelajaran, sifat materi pelajaran, karakteristik pembelajaran, media dan fasilitas pembelajaran yang tersedia. Pembelajaran yang dirancang dan berpijak pada teori behavioristik memandang bahwa pengetahuan adalah obyektif, pasti, tetap, tidak berubah. Pengetahuan telah terstruktur dengan rapi, sehingga belajar adalah perolehan pengetahuan, sedangkan mengajar adalah memindahkan pengetahuan (transfer of knowledge) ke orang yang belajar atau peserta didik. Fungsi mind atau pikiran adalah untuk menjiplak struktur pengetahuan yag sudah ada melalui proses berpikir yang dapat dianalisis dan dipilah, sehingga makna yang dihasilkan dari proses berpikir seperti ini ditentukan oleh karakteristik struktur pengetahuan tersebut. Menurut Kim (1992) behavioris berasumsi bahwa tujuan pembelajaran yang penting dapat ditentukan dan diukur sepenuhnya, dan beberapa behavioris berpendapat bahwa mengajar bertujuan untuk menciptakan instruksi yang baik. Peserta didik diharapkan akan memiliki pemahaman yang sama terhadap pengetahuan yang diajarkan. Artinya, apa yang dipahami oleh pengajar atau guru itulah yang harus dipahami oleh murid. Demikian halnya dalam pembelajaran, pembelajar dianggap sebagai objek pasif yang selalu membutuhkan motivasi dan penguatan dari pendidik. Oleh 
karena itu, para pendidik mengembangkan kurikulum yang terstruktur dengan menggunakan standar-standar tertentu dalam proses pembelajaran yang harus dicapai oleh para peserta didiknya. Begitu juga dalam proses evaluasi belajar peserta didik diukur hanya pada hal-hal yang nyata dan dapat diamati sehingga hal-hal yang bersifat tidak teramati kurang dijangkau dalam proses evaluasi.

Implikasi dari teori behavioristik dalam proses pembelajaran dirasakan kurang memberikan ruang gerak yang bebas bagi pembelajaran untuk berkreasi, bereksperimentasi dan mengembangkan kemampuannya sendiri. Karena sistem pembelajaran tersebut bersifat otomatis-mekanis dalam menghubungkan stimulus dan respon sehingga terkesan seperti kinerja mesin atau robot. Akibatnya pembelajar kurang mampu untuk berkembang sesuai dengan potensi yang ada pada diri mereka. Karena teori behavioristik memandang bahwa pengetahuan telah terstruktur rapi dan teratur, maka peserta didik atau orang yang belajar harus dihadapkan pada aturan-aturan yang jelas dan ditetapkan terlebih dulu secara ketat. Pembiasaan dan disiplin menjadi sangat esensial dalam belajar, sehingga pembelajaran lebih banyak dikaitkan dengan penegakan disiplin. Kegagalan atau ketidakmampuan dalam penambahan pengetahuan dikategorikan sebagai kesalahan yang perlu dihukum dan keberhasilan belajar atau kemampuan dikategorikan sebagai bentuk perilaku yang pantas diberi hadiah. Demikian juga, ketaatan pada aturan dipandang sebagai penentu keberhasilan belajar. Peserta didik adalah objek yang berperilaku sesuai dengan aturan, sehingga kontrol belajar harus dipegang oleh sistem yang berada di luar diri peserta didik. Metode penguatan behavioristik sangat efektif dalam menciptakan perilaku positif pada lingkungan belajar. Metode seperti itu secara positif mempengaruhi pembelajaran pada peserta didik (Faryadi, 2007).
Tujuan pembelajaran menurut teori behavioristik ditekankan pada penambahan pengetahuan, sedangkan belajar sebagi aktivitas "mimetic", yang menuntut peserta didik untuk mengungkapkan kembali pengetahuan yang sudah dipelajari dalam bentuk laporan, kuis, atau tes. Penyajian isi atau materi pelajaran menekankan pada ketrampian yang terisolasi atau akumulasi fakta mengikuti urutan dari bagian ke keseluruhan. Pembelajaran mengikuti urutan kurikulum secara ketat, sehingga aktivitas belajar lebih banyak didasarkan pada buku teks/buku wajib dengan penekanan pada ketrampilan mengungkapkan kembali isi buku teks/buku wajib tersebut. Pembelajaran dan evaluasi menekankan pada hasil belajar.

Evaluasi menekankan pada respon pasif, ketrampilan secara terpisah, dan biasanya menggunakan paper and pencil test. Evaluasi hasil belajar menuntut jawaban yang benar. Maksudnya bila peserta didik menjawab secara "benar" sesuai dengan keinginan guru, hal ini menunjukkan bahwa peserta didik telah menyelesaikan tugas belajarnya. Evaluasi belajar dipandang sebagi bagian yang terpisah dari kegiatan pembelajaran, dan biasanya dilakukan setelah selesai kegiatan pembelajaran.

\section{3) Bentuk Pelaksanaan Metode Pembelajaran Behavioristik}

Penerapan teori belajar Behavioristik dalam pendidikan menurut Irham \& Wiyani (2015) terlihat dalam beberapa hal diantaranya: (1) bahan-bahan pengajaran sudah siap digunakan; (2) bahan pelajaran tersusun secara hierarkies, dari sederhana ke rumit dan kompleks; (3) pembelajaran berorientasi hasil yang terukur dan teramati 
dalam bentuk perilaku yang diinginkan; (4) pengulangan dan latihan digunakan untuk membentuk kebiasaan; (5) apabila perilaku yang diinginkan muncul diberi penguatan positif dan yang kurang diinginkan mendapat penguatan negatif. Proses pembelajaran yang berpijak pada teori belajar Behavioristik adalah sebagai berikut: (1) menentukan tujuan pembelajaran dalam bentuk standart kompetensi (SK) dan kompetensi dasar (KD) serta indikator ketercapaian; (2) menentukan materi pelajaran yang akan diberikan; (3) merinci materi menjadi bagaian-bagaian kecil dalam bentuk pokok bahasan, sub pokok bahasan, dan sebagainya; (4) memberikan stimulus berupa pertanyaan-pertanyaan, latihan-latihan, dan tugastugas dalam proses pembelajaran; (5) adanya aktivitas memberikan hadiah dan hukuman (Sugiyono \& Hariyanto, 2011).

Metode pembelajaran Behavioristik tidak cocok digunakan untuk semua mata pelajaran karena pada dasarnya metode pembelajaran behavioristik membutuhkan praktik dan pembiasaan misalnya percakapan menggunakan bahasa asing, olahraga, penggunaan komputer dan lain sebagainya yang membutuhkan latihan dan pembiasaan. Menurut Sanyata Perkembangan pendekatan Behavioristik mempunyai konstribusi besar terhadap pencapaian target konseling untuk mencapai tujuan perubahan pikiran, perasaan dan perilaku. Metode belajar behavioristik diterapkan untuk melatih dan membimbing anak yang membutuhkan dorongan dari orangtua, suka meniru, dan suka mengulangi perilaku setelah mendapatkan reward atau hadiah, dan dari uraian diatas dapat disimpulkan bahwasanya konsep pembelajaran dalam teori belajar behavioristik sebagai ajang pelatihan agar terbentukya perilaku yang akibat dari adanya hubungan stimulus-respon yang terjadi berulangulang kali dengan adanya dukungan hadiah dan hukuman.
4) Kelebihan dan Kekurangan Teori

\section{Behaviorisme}

Kaum behavioris menjelaskan belajar merupakan suatu proses perubahan tingkah laku dimana penguatan dan penghargaan, serta hukuman menjadi stimulus untuk merangsang siswa dalam berperilaku. Para pendidik biasanya menggunakan teori behaviorisme untuk merencanakan kurikulum dengan menyusun isi pengetahuan menjadi bagian-bagian kecil yang ditandai dengan suatu keterampilan tertentu (Rahyubi, 2012). Adapun kekurangan dan kelemahan dari teori behaviorisme seringkali dikritik karena tidak mampu menjelaskan situasi belajar yang kompleks. Teori ini selalu menyederhanakan hal-hal yang berkaitan dengan pendidikan dan atau belajar sekedar pada hubungan stimulus dan respon saja serta tidak mampu menjelaskan penyimpangan-penyimpangan yang terjadi dalam hubungan stimulus dan respon itu sendiri. Selain itu, teori behaviorisme ini juga kurang mampu menjelaskan tentang adanya variasi tingkat emosi siwa, meskipun mereka memiki pengalaman penguatan yang sama. Teori ini tidak dapat menjelaskan mengapa dua anak yang mempunyai kemampuan dan pengalaman penguatan yang relatif sama ternyata perilakunya terhadap suatu pelajaran berbeda, juga dalam memilih tugas sangat berbeda tingkat kesulitannya. Jadi teori ini hanya mengakui adanya stimulus dan respon yang dapat diamati, dan tidak memperhatikan keberadaan pengaruh pikiran ataupun perasaan yang mempertemukan unsur-unsur yang diamati tersebut.

Teori behaviorisme juga cenderung mengarahkan siswa berpikir linier, tidak produktif dan tidak kreatif. Pandangan teori ini yang mengatakan bahwa belajar merupakan proses pembentukan, yaitu 
membawa siswa menuju atau mencapai target tertentu, menjadikan siswa tidak bebas berkreasi dan berimajinasi. Padahal, banyak faktor yang mempengaruhi proses belajar. Sedangkan kelebihan dan kekuatan memiliki kontribusi nyata untuk membentuk kedisiplinan dan tanggung jawab. Kedisiplinan dan tanggung jawab merupakan elemen penting dalam proses belajar dan pembelajaran. Kedisiplinan dan tanggung jawab juga merupakan karakter manusia yang utama.

\section{SIMPULAN}

Teori belajar behavioristik merupakan suatu bentuk perubahan yang dialami individu berupa kemampuan dalam bentuk perubahan tingkah laku dengan cara yang baru sebagai hasil dari adanya stimulus dan respon. Teori belajar behavioristik memiliki ciri-ciri diantaranya adalah mementingkan faktor lingkungan, perkembangan tingkah laku seseorang itu tergantung pada belajar, menekankan pada faktor bagian (elemenelemen dan tidak secara keseluruhan), sifatnya mekanis atau mementingkan reaksi kebiasaankebiasaan, mementingkan masa lalu atau bertinjauan historis artinya segala tingkah lakunya terbentuk karena pengalaman dan latihan.

Aplikasi teori behavioristik dalam kegiatan pembelajaran tergantung dari beberapa hal seperti: tujuan pembelajaran, sifat materi pelajaran, karakteristik pembelajaran, media dan fasilitas pembelajaran yang tersedia. Pembelajaran yang dirancang dan berpijak pada teori behavioristik memandang bahwa pengetahuan adalah obyektif, pasti, tetap, tidak berubah.

Implikasi dari teori behavioristik dalam proses pembelajaran dirasakan kurang memberikan ruang gerak yang bebas bagi pembelajaran untuk berkreasi, bereksperimentasi dan mengembangkan kemampuannya sendiri.

Metode belajar behavioristik diterapkan untuk melatih dan membimbing anak yang membutuhkan dorongan dari orangtua, suka meniru, dan suka mengulangi perilaku setelah mendapatkan reward atau hadiah, dan dari uraian diatas dapat disimpulkan bahwasanya konsep pembelajaran dalam teori belajar behavioristik sebagai ajang pelatihan agar terbentukya perilaku yang akibat dari adanya hubungan stimulus-respon yang terjadi berulang-ulang kali dengan adanya dukungan hadiah dan hukuman. 


\section{DAFTAR PUSTAKA}

Bungin, B. (2008). Penelitian Kualitatif: Komunikasi, Ekonomi, Kebijakan Publik dan Ilmu Sosial Lainnya. Jakarta: Kencana.

Faryadi, Q. (2007). Behaviorism and the Construction of Knowledge. Diakses di https://eric.ed.gov/?q=behaviorist+learning $\& \mathrm{ft}=$ on\&id=ED495301.

Husamah, Pantiwati, Restian, and Sumarsono. (2018). Belajar \& Pembelajaran. Malang: UMM Press.

Irham, W. (2015). Psikologi Pendidikan Teori dan Aplikasi dalam Proses Pembelajaran. Jogjakarta; Arr-Ruzz Media.

Kim, J. (1992). Three Approaches For The Integration of Teaching, Testing, and Learning. Diakses di https://eric.ed.gov/?q=behaviorist+learning \&ft=on\&pg=4\&id=ED354250.

Rahyubi, H. (2012). Teori-teori Belajar dan Aplikasi Pembelajaran Motorik: Deskripsi dan Tinjauan Kritis. Bandung: Nusa Media.

Sanyata, S. (2012). Teori dan Aplikasi Pendekatan Behavioristik dalam Konseling. Jurnal Paradigma. 14 Th. VII, Juli 2012.

Soesilo, T. D. (2015). Teori dan Pendekatan Belajar Aplikasinya dalam Pembelajaran. Yogyakarta: Penerbit Ombak.

Sugihartono, dkk. (2007). Psikologi Pendidikan. Yogyakarta: UNY Press.

Sugiono. (2005). Memahami Penelitian Kualitatif. Bandung: Alfabeta.

Sugiyono., H. (2011). Belajar dan Pembelajaran Teori dan Konsep Dasar. Bandung: Remaja Rosdakary 
